\title{
Monterrey envisioned as a smart city developed through international model examples
}

\author{
P. Phumpiu Chang \& J. L. Rivera Kuri \\ Tecnológico de Monterrey, Mexico
}

\begin{abstract}
Cities evolve constantly and adjust to new requirements. The fragmented vision of a city leads to design and elaborate strategies focused on some issues, letting others aside failing to develop the city strategies as a whole. Cities of today are analyzed with features based on the three pillars of sustainability, social environment and economic environment, as the driving forces to achieve quality of life. Nevertheless, modern cities find themselves contested in their technological endeavour and in their social reclamation of urban spaces. The great majority of technology and smart cities' detractors do not believe technology could offer features to attain quality in the social environment. Social and technology features could attain visions of sustainability, only if they are integrated to economic strategies to make them sustainably feasible. The objective of this paper is to analyse case studies with the characteristics of sustainability as well as of the smart city in the attempt to merge features that are commonly fragmented and thus to create a broader perspective for designing strategies. The built environment and social network created under a feasible financing scheme are the support for the ultimate goal that is to generate the sustainability culture where technology engineers share the leading role with environmental and social professionals. The result is the identification of opportunities for Monterrey, Mexico, to guide its beginning path towards a smart-sustainable city.

Keywords: smart city, sustainable cities, urban built infrastructure, technology, Barcelona, Curitiba, Singapore, Hammarby Sjöstad, Monterrey.
\end{abstract}

\section{Introduction}

The purpose of this paper is to understand the trends and the development path of Smart City Models in order to take the lessons learned and successful cases of study as a pattern useful in urban renovations and sustainable development in 
Latin American cities, particularly in Monterrey, Mexico. Analyzing sustainability and its principles, cases of study that have become models well-known internationally, such as "Barcelona Model", Curitiba, Hammarby Sjöstad (Stockholm) and Singapore. Classifying their main components in a framework able to lead the development of cities like Monterrey.

\section{Defining smart city and sustainable urban development}

What is a city? We are living in cities of the third generation, where the street and the people are re-recognized as the main elements of the city and where physical infrastructure is complementary and compulsory.

How could a city be sustainable? How could a city induce people to sustainable development? Sustainable development refers to meet the needs of the present meanwhile conserving resources for the future (WCED [1]). Still the question arise at the meaning of "needs" for today's society where needs could refer to demands without considering the supply of resources. Sustainable city is conceptualized by Soltani and Sharifi [2] (2012) as a city where three main components coexist: economy, environment and social equity, we could add people and streets - public space.

It is common to classify sustainable principles of urban development into managerial, social-economic and ecological. Managerial is related to government environmental understanding and responsibilities, environmental policies and strategic city planning in a long-term periodicity. Socio-economical principle includes standard regulations, survey economy and culture with the appropriate environmental indicators, market networks, citizenship and social acceptability, technology and design. Ecological principles include producing the minimum amount of waste, using minimum resources or maximizing recycled and renewable materials and alternative energies, integrated activities and respect to the environment (Soltani and Sharifi). But by and large, it is the public space what is defining the quality of the city, as well as the elements that create it.

Concepts on sustainable cities have taken different variants one of them being smart city. Smart City is an emerging concept, which definition is still in progress. Chourabi et al. [3] (2012) define Smart City as one where several dimensions coexist such as: economy, people, governance, mobility, environment, quality of life and technology. The integrated dimensions lead to monitoring and integrating city's infrastructure to optimize resources, connectivity in-between the physical and the Information Technologies (IT) infrastructure, efficiency and sustainability of its utilities, innovation in city management solutions, and intelligent transportation (Chourabi et al. [3]).

\section{Urban dimension analysis in case studies}

The criteria for the analysis is taken from the dimensions that Chourabi et al. [3] place as the framework for smart cities conceptualization: (1) management and organization, (2) technology, (3) governance, (4) policy, (5) people and communities, (6) the economy and finance, (7) built infrastructure - urban 
transport, water management, alternative energies, waste management and recycling, (8) the natural environment. The case studies selected for this paper analysis are Barcelona, Curitiba, Singapore, Hammarby Sjöstad in Stockholm and Monterrey.

Table 1: Checklist of a smart city framework analysis.

\begin{tabular}{|l|c|c|c|c|c|}
\hline & $\begin{array}{l}\text { Barcelona } \\
1900-@ 22\end{array}$ & Curitiba & Singapore & $\begin{array}{l}\text { Hammarby } \\
\text { Sjöstad }\end{array}$ & Monterrey \\
\hline Management and organization & $\checkmark$ & $\checkmark$ & & & \\
\hline Technology & & $\checkmark$ & $\checkmark$ & & \\
\hline Governance & $\checkmark$ & $\checkmark$ & $\checkmark$ & $\checkmark$ & \\
\hline Policy & $\checkmark$ & $\checkmark$ & $\checkmark$ & $\checkmark$ & $\checkmark$ \\
\hline People and communities & $\checkmark$ & $\checkmark$ & $\checkmark$ & $\checkmark$ & $\checkmark$ \\
\hline Economy & $\checkmark$ & $\checkmark$ & $\checkmark$ & $\checkmark$ & $\checkmark$ \\
\hline Built infrastructure & $\checkmark$ & $\checkmark$ & $\checkmark$ & $\checkmark$ & \\
\hline Natural environment & $\checkmark$ & $\checkmark$ & $\checkmark$ & $\checkmark$ & \\
\hline
\end{tabular}

\subsection{Management and organization}

None implementation for revitalization and rehabilitation of a city is possible without management with proper expertise and organization. The case studies of Barcelona, Curitiba and Singapore have followed management leadership and organization of all dimensions in order to have an integrative solution. Monterrey may be struggling with a coordinated planning and implementation as we will set up in the second section.

Barcelona's city renovation and urban planning have been led by a strong public-private organization. Governments in Barcelona, Curitiba and Singapore have historically been in favour of the active role of the entrepreneurship and industry in the city development, as well as the public-private partnerships. Hammarby Model, as a district of Stockholm it has a strong public organization, also business association promotion but it has a distinctive characteristic: the importance of the Co-operatives in the public and private concerns. There are cooperatives that help out in the important state policies' development through programmes such as public housing.

Cities have their own strategy to undergo urban renovation and management. A Historical track for management, organizations and policies towards their consolidation for a Smart Sustainable City are presented in table 2.

\subsection{Governance}

Governance is defined as the participation of stakeholders among several processes of information exchange according to rules and standards (Johnston and Hasten in Chourabi et al. [3]). Governance is also defined as the process to conceptualize the desire social future with a social agenda where work is divided, authority and responsibilities distributed among stakeholders (Aguilar Villanueva [5]). Our studies show coordination with a governance mechanism taken by all stakeholders, definitely a group of entities from the government, private sector and civil society has participated to make feasible their city plans. 
Table 2: Historical approach for urban renovation.

\begin{tabular}{|c|c|c|c|c|c|}
\hline City & \multicolumn{5}{|c|}{ Urban renovation strategies } \\
\hline Barcelona & $\begin{array}{l}\text { People's physical, } \\
\text { mental and social } \\
\text { health designing: } \\
\text { Cerdá. (1859). }\end{array}$ & $\begin{array}{l}\text { Monumentality } \\
\text { - Urban Policy } \\
-(1901) .\end{array}$ & $\begin{array}{l}\text { Network plan: } \\
\text { Puig i } \\
\text { Cadalfach } \\
(1903) \text {. }\end{array}$ & $\begin{array}{l}\text { Zoning } \\
\text { Techniques and } \\
\text { City } \\
\text { Beautification: } \\
\text { León Jaussely } \\
(1907) .\end{array}$ & $\begin{array}{l}\text { "Urban } \\
\text { Acupuncture" } \\
\text { - public spaces } \\
\text { recovery - and } \\
\text { hygienization } \\
(1986) \text {. }\end{array}$ \\
\hline Curitiba & $\begin{array}{l}\text { "Star of } \\
\text { Boulevards" } \\
\text { integrating all } \\
\text { services } \\
\text { downtown, } \\
\text { industrial district } \\
\text { and sanitation } \\
\text { infrastructure: } \\
\text { Alfred Agache } \\
(1940) \text {. }\end{array}$ & $\begin{array}{l}\text { Control urban } \\
\text { sprawl, preserve } \\
\text { historical area, } \\
\text { reduce traffic } \\
\text { (BRT system): } \\
\text { Jaime Lerner } \\
(1964-1968) .\end{array}$ & $\begin{array}{l}\text { 2010: "Globe } \\
\text { Sustainable } \\
\text { City Award". } \\
\text { Integral Urban } \\
\text { Plan and } \\
\text { practical design } \\
\text { solutions. }\end{array}$ & $\begin{array}{l}\text { Greenery. Social } \\
\text { sustainability } \\
\text { consciousness, } \\
\text { citizenship } \\
\text { sense and } \\
\text { participation. } \\
(1979-2010) .\end{array}$ & $\begin{array}{l}\text { Transport } \\
\text { System and } \\
\text { land use } \\
\text { projection } \\
(1964) .\end{array}$ \\
\hline $\begin{array}{l}\text { Stockholm } \\
\text { (Hammarby } \\
\text { Sjöstad) }\end{array}$ & $\begin{array}{l}\text { Brownfield } \\
\text { adjacent to } \\
\text { Stockholm's } \\
\text { centre. }\end{array}$ & $\begin{array}{l}\text { An industrial } \\
\text { waterfront } \\
\text { redevelopment } \\
\text { planning } \\
(1996) .\end{array}$ & $\begin{array}{l}2004 \text { Olympic } \\
\text { bid considered } \\
\text { to develop the } \\
\text { area. }\end{array}$ & $\begin{array}{l}\text { Sustainable } \\
\text { community } \\
\text { twice as } \\
\text { efficient as a } \\
\text { standard one } \\
(2000-2012) \text {. }\end{array}$ & $\begin{array}{l}\text { The Hammarby } \\
\text { Model is based } \\
\text { on a closed- } \\
\text { loop "urban } \\
\text { metabolism". }\end{array}$ \\
\hline Singapore & $\begin{array}{l}\text { City } \\
\text { Beautification: } \\
\text { "Garden City" } \\
(1970) . \\
\text { Urban } \\
\text { Redevelopment } \\
\text { Authority (URA) } \\
\text { with planning and } \\
\text { development } \\
(1971) .\end{array}$ & $\begin{array}{l}\text { Master and } \\
\text { Concept Plan: } \\
\text { Quality of life. } \\
\text { Objectives: } \\
\text { good living } \\
\text { environment, } \\
\text { inclusive } \\
\text { society, } \\
\text { belonging sense } \\
\text { and economic } \\
\text { growth. }\end{array}$ & $\begin{array}{l}\text { Parks and } \\
\text { Water-bodies } \\
\text { Plan: } \\
\text { Recreational } \\
\text { space (2002). } \\
\text { Leisure Plan } \\
(2008) .\end{array}$ & $\begin{array}{l}\text { Conservation of } \\
\text { Built Heritage: } \\
\text { unique character } \\
\text { and sense of } \\
\text { history (2011). }\end{array}$ & $\begin{array}{l}\text { Marina Bay: } \\
\text { Dynamic } \\
\text { District "live, } \\
\text { work and } \\
\text { play". }\end{array}$ \\
\hline
\end{tabular}

The case studies presented are good examples for transversal cooperation. The new Barcelona Model favours the networking among professionals of different areas and encourages innovation and collaboration, an integral synergy among enterprises, institutions, social, educational and cultural organizations and citizens. The Barcelona City Council is absolutely in favour of enterprises (Socrates [6]). In Singapore the Urban Redevelopment Authority (URA), the National Environmental Agency (NEA), the National Water Agency (NWA), the Land Transport Authority (LTA) and the Building and Construction Authority (BCA) working together with the local government indirectly connected to official state authorities, private sector in projects that promote the insurance of natural resources' reservoirs, construction and maintenance of facilities and infrastructure.

In Curitiba, a historical collaboration among scholars, government and industrialists, investors - the private sector - brings together city planning, projection and the physical interventions via public transportations infrastructure and preservation of natural spaces. Hammarby, as a single district, is relevant due to its international recognition as a sustainable city model- and moreover due to 
the management dependent on local stakeholders and city government, investors, developers, architecture, engineering and construction firms and local co-operatives where management also includes residents consumption.

\subsection{Policy}

Policy context is crucial to make urban projects feasible. For urban projects, normative context is usually the first obstacle. Policy usually needs to adapt to new institutional arrangements and technology and non-technical or organizational issues (Yigicantlar in Chourabi et al. [3]). Barcelona, Curitiba and Singapore are cities that have been transformed following urban development plans. On the contrary, Hammarby Sjöstad is a new development that needed to adapt to existing policy due to new institutional arrangements among private sector and civil society actors to create and enable a new concept of urban development.

There have been along the historical course several policies that beyond the regulations had led to cooperation in between different governmental agents in different levels - federal-municipal, scholars, entrepreneurs, industrial business men and investors and including the citizenship participation. The promotion of mega-urban projects in a city has regularly depended on different governmental levels and a proactive role of the private sector and the academic association.

\subsection{IT technology}

Information Technology, could be defined as the acquisition, processing, storage and spread of information of all kind through the computer technologies and telecommunication systems (Williams [7]). Technology is to Chourabi et al. [3] "a set of computing technologies". One of the key components of smart cities is defined by its Information Technology (IT) capacity, which brings the opportunity to integrate different controls and monitoring the stages of projects development, operation and maintenance.

Curitiba, Singapore and Hammarby Sjöstad are the cases complying with the aspect of Information and Communication Technology (ICT) to optimize processes. As Chourabi et al. [3] point out the advantages ICT brings to quality of life, but for its successful implementation is mandatory to consider institutional willingness, building capacity and meeting the user's requirements. ICT also have setbacks by creating inequalities and changing culture and habits (Odendaal [8]) that should be considered before taking the decision of implementing ICT.

\subsection{People and communities}

New cities and the third generation of cities are about public spaces, services and quality of life, they are not only about normative aspects and technology; new cities must be human focused. Idelfons Cerdá, since mid-1800s, reminded us that the street, as a part of a social and urban organism, provides a set of services. Among the dimensions a city should include, Chourabi enumerates: education, sense of citizenship and proactive participation of actors and partnerships (Chourabi et al. [3]). Quality of life is brought to new cities by human values 
reinforced in the practice of regulation by volunteerism and new initiatives. In the four urban areas as case studies, people are the centre for urban planning and restructuring the city. The five cities discussed in this paper have had an intense participation of people in their management context. In some cases they participate directly to achieve common aims and goals.

The 1800s Cerdá's plan to sanitize and build public spaces in Barcelona as a city conceived to improve people in each one of its dimensions - physical, mental and social health - was a milestone to become a European model. Nevertheless, the city of today has challenges that we cannot ignore; today it faces a society of information and dispersed, a more regional than metropolis contained. Thus, the 22@Barcelona project, contemplates to attract qualified professionals as a determining factor for enterprises to settle down in an area. Barcelona and its metropolitan area have a proven and highly qualified work force that has been selected by over 250 innovative enterprises to set up their Headquarters (Socrates). Barcelona also has the competitive advantage of being qualified as one of the best European cities in terms of their people's quality of life.

Singapore, as a contemporary city facing these challenges, sets an example of human based political leadership to ensure quality of life and security with the construction of the Marina Barrage, a multidisciplinary facility that incorporates flood control system, water reservoir and a solar park. More than that, the Marina promotes social consciousness and then again the importance of community. So the attractiveness of a city falls on its acknowledgement of quality of life offered from people to people, the community it holds and integrates.

\subsection{Economy}

Urban development plans depend on the economic means. Partnerships and joint ventures promote innovation, entrepreneurship and industrial development through the communication and dialogue among stakeholders. For urban housing renovation in Barcelona they designed interesting incentive programmes to renew the inside of the buildings, not only façade renovations. In many other ways people and community are approached to generate consumption savings as in Hammarby Sjöstad, and in regulatory governance in the cities of Curitiba and Singapore.

In Barcelona and Singapore the flagship events and projects have been the driving force to economic dynamism and development of the city in post-industrial stages. For Barcelona the 1992 Olympic Games as well as 2004 Universal Forum of Cultures marked a milestone to its international positioning as a cultural European capital (Casellas [9]). Barcelona could overcome the post-Olympics phase with a scheme of production-consumption culture promotion through the establishment of "thematic park" neighborhoods. The same pattern of consumption spaces creation is observed in Singapore (Henderson [10]) with mega-flagship projects as the Marina Bay, they have consolidated the city as Asian major business and financial hub.

Hammarby Sjöstad itself is a major urban development project that enhanced the economic growth and investment attraction in Stockholm by its positioning as an international model of sustainability. In Curitiba the environmental 
consciousness of the industrial development has led to major investments and attracted capitals with its quality of life labeled city.

During last years, the industry of technology is the focus in developing cities. The Barcelona 22@Barcelona Project aims to integrate new technological revolution merged with knowledge economy (Leon [11]). The goal of technology development (Barcelo [12]) is to achieve a high quality, compact, mixed, sustainable urban model that could lead to balance ecology with economics and city cohesion.

\subsection{Built infrastructure}

As Chourabi et al. [3] established: "availability and quality of the ICT infrastructure are important for smart cities". Moreover, smart cities are not only about ICT, but also about the integration into a holistic perspective of all the technologies applied to cities' infrastructure and their link with ITs, security, monitoring, control, operation costs and maintenance. Technology requires knowledge management and building capacity to understand the way it operates and why is it necessary. In developed countries the significance and commitment from people and communities towards taking care of infrastructure is more commonly-held. The model used in each of the cases studies focus on infrastructure first to sanitize the city, as in Barcelona, during the first urban renovation mid-1800s. And later urban models evolved to technology with live environment.

\section{Built infrastructure: urban sustainability and technologies}

Dispersion, segregation and fragmentation are the challenges for the city of today which we are to re-define in terms of the urban built environment and infrastructure - technology based. Technologies are decisive to move towards this new city and to sustainability, although high technology is not the only component. Having it said, sustainable cities are also about environment, the built environment and the infrastructure that supports the environment: urban transport systems, water technology, alternative energies usage and waste management and recycling.

\subsection{Urban transport}

Urban transport is one of the core sustainable strategies to achieve sustainability referring to mass transportation. Barcelona Olympic areas and Hammarby as well as a new urban district were out of reach of urban mass transportation network, thus it was important to link them to the urban grid. Curitiba and Singapore, on the other hand, renovated their urban transportation system and made it more attractive to people so they could choose to ride them instead of choosing their cars. 
Table 3: Framework for built infrastructure technologies towards urban sustainable development.

\begin{tabular}{|c|c|c|c|c|c|}
\hline City & Urban planning & $\begin{array}{l}\text { Urban } \\
\text { Transport }\end{array}$ & $\begin{array}{l}\text { Water } \\
\text { Technology }\end{array}$ & $\begin{array}{l}\text { Alternative } \\
\text { Energy }\end{array}$ & $\begin{array}{l}\text { Waste } \\
\text { Management and } \\
\text { Recycling } \\
\end{array}$ \\
\hline Barcelona & $\begin{array}{l}\text { The Barcelona } \\
\text { Model, } \\
\text { 22@Barcelona }\end{array}$ & $\begin{array}{l}\text { Ring road } \\
\text { system around } \\
\text { the city, dense } \\
\text { underground } \\
\text { network, } \\
\text { European top } \\
\text { class port, High } \\
\text { Speed Train } \\
\text { Connection } \\
\end{array}$ & $\begin{array}{l}\text { Potable- } \\
\text { drinkable } \\
\text { water in every } \\
\text { single home } \\
\text { and utility in } \\
\text { the city }\end{array}$ & & $\begin{array}{l}\text { Recycling via } \\
\text { classification, an } \\
\text { important } \\
\text { infrastructure of } \\
\text { differentiated } \\
\text { deposits. } \\
\text { Automat truck } \\
\text { Waste Collection } \\
\text { System } \\
\end{array}$ \\
\hline Curitiba & $\begin{array}{l}\text { Urban } \\
\text { development } \\
\text { policies designed } \\
\text { to control urban } \\
\text { sprawl }\end{array}$ & $\begin{array}{l}\text { BTR system } \\
\text { pedestrian and } \\
\text { bicycle } \\
\text { preference }\end{array}$ & $\begin{array}{l}\text { Sewage } \\
\text { treatment } \\
\text { system through } \\
\text { local lagoons }\end{array}$ & & $\begin{array}{l}\text { Garbage } \\
\text { classification and } \\
\text { recycling system } \\
\text { hiring the } \\
\text { homeless and } \\
\text { rehabs }\end{array}$ \\
\hline $\begin{array}{l}\text { Hammarby- } \\
\text { Sjöstad, } \\
\text { Stockholm }\end{array}$ & $\begin{array}{l}\text { The Hammarby } \\
\text { Model }\end{array}$ & $\begin{array}{l}\text { Transit } \\
\text { Oriented } \\
\text { Development } \\
\text { (TOD), } \\
\text { walkability, } \\
\text { tramway, ferry, } \\
\text { underground } \\
\text { connection, bus } \\
\text { driven by } \\
\text { biogas, car pool } \\
\text { system } \\
\text { (biogas), safe } \\
\text { cycling lane } \\
\text { network }\end{array}$ & $\begin{array}{l}\text { Rain water } \\
\text { collection and } \\
\text { filtration } \\
\text { system, own } \\
\text { treatment } \\
\text { plant }\end{array}$ & $\begin{array}{l}\text { Solar-energy } \\
\text { utilities, } \\
\text { biogas }\end{array}$ & $\begin{array}{l}\text { Recycling } \\
\text { Vacuum system } \\
\text { for solid waste } \\
\text { and refuse } \\
\text { sorting, } \\
\text { conducting from } \\
\text { dwelling to } \\
\text { industry by a } \\
\text { pressurized tubed } \\
\text { underground } \\
\text { network. Waste } \\
\text { management } \\
\text { Hammarby }\end{array}$ \\
\hline Singapore & $\begin{array}{l}\text { Singapore: } \\
\text { Sustainable City } \\
\text { Model. Post- } \\
\text { industrial mega- } \\
\text { flagship projects } \\
\text { and consumption } \\
\text { spaces }\end{array}$ & $\begin{array}{l}\text { Intelligent } \\
\text { Transport } \\
\text { System (ITS). } \\
\text { Interactive } \\
\text { MRT System } \\
\text { Map, Bus } \\
\text { Services } \\
\text { enhancement } \\
\text { program }\end{array}$ & $\begin{array}{l}\text { National Water } \\
\text { Agency: ABC } \\
\text {-"Active, } \\
\text { Beautiful, } \\
\text { Clean"- Waters } \\
\text { Program. } \\
\text { Collection of } \\
\text { rainfall, } \\
\text { Treatment of } \\
\text { raw to potable } \\
\text { and sewage } \\
\text { waters, } \\
\text { desalination }\end{array}$ & $\begin{array}{l}\text { Solar Energy } \\
\text { Park in the } \\
\text { Marina } \\
\text { Barrage }\end{array}$ & $\begin{array}{l}\text { National } \\
\text { Environmental } \\
\text { Agency: Solid } \\
\text { Waste } \\
\text { Management and } \\
\text { Recycling } \\
\text { systems in } \\
\text { Singapore }\end{array}$ \\
\hline Monterrey & $\begin{array}{l}\text { Urban } \\
\text { Development } \\
\text { Planning } \\
\text { Monterrey } 2020\end{array}$ & $\begin{array}{l}\text { Bus Service, } \\
\text { BRT, Light } \\
\text { Rail Transit } \\
\text { System }\end{array}$ & $\begin{array}{l}\text { Potable water } \\
\text { supply system } \\
\text { extended all } \\
\text { over the city }\end{array}$ & $\begin{array}{l}\text { Santa } \\
\text { Catarina's 22 } \\
\text { MWatt Wind } \\
\text { Farm }\end{array}$ & $\begin{array}{l}\text { Automated } \\
\text { collection. } \\
\text { SEMARNAT's } \\
\text { Waste } \\
\text { Management } \\
\text { Regulations } \\
\end{array}$ \\
\hline
\end{tabular}


Barcelona's ring road system as well as Curitiba bus transport system (BTS) and integrated transport network (RIT) developed a dense transportation network. In Barcelona railways and buses complemented the road system to hold a European top class port. The High-Speed Train in Barcelona is connected with the European network since 2009 (Socrates). The BTS in Curitiba also controls over the urban sprawl where urban planning and densification policies have been determined by the access to the public transport network. $85 \%$ of the population in Curitiba uses the system, which is the reason of how the population doubled where since 1974 while the car traffic reduced by $30 \%$. The cost of urban mobility declines due to the reduction of the fuel consumption and carbon footprint.

Hammarby Sjöstad's Transit Oriented Development (TOD), provides access to this new urban district with mass transportation. They developed a car pool system fueled by biogas and a safe cycling lane network. Mass transportation in Hammarby is beyond mobilizing people, the system is environmentally driven by a highly developed tramway, ferry, underground connection and bus network on biogas produced at its own sewage water treatment plant (Gaffney et al. [4]). Thus, transportation network was designed to link walking areas connected to public spaces, both the promenade areas and the mass transportation surroundings. The Hammarby district belongs to the city of Stockholm where culturally cycling is a priority.

Singapore's strategy for mass transportation develops from a land transport policy (1996) which purpose is to reduce traffic congestion. The main land transport strategies (LTA [13]) can be summarized as integrating land use and transportation planning to minimize travel demand and maximize use of road space; an expansion of the road network to maximize its capacity and provide accessibility; integrating rail, bus and taxi services; designing travel demand management and improving traffic management measures. Singapore promotes social responsibility being the first city to use Electronic Road Pricing (ERP) system on an extensive scale to manage traffic congestion (Tuan [14]), thus providing social equitable, flexible and reliable system.

Monterrey has a poor transport infrastructure that includes 201 Bus Routes (163 radial routes, 23 peripheral routes and 15 Bus Rapid Transit routes) and 65 minibus routes. The city of Monterrey is overwhelmed with the operation of approximately 4,036 buses, 1,066 minibuses and 28,261 taxi cars. The city counts with two light rail transit service lines running over $24 \mathrm{~km}$ length, throughout 25 stations with 110,670 passengers/day capacity (measured in august 2002). By comparing the mass public transportation with the private transportation, the first represents a $2.52 \%$ with 5 million trips per day, and private transport fleet runs $97.48 \%$ with only 2.7 million trips per day. A city with 1.2 million of inhabitants holds 1,210,252 private automobiles in 2003 according to the Monterrey Metropolitan Area vehicle record (Gobierno-Municipal-de-Monterrey [15]). Which is a clear, convincing proof of the relation between a lack of a dense public transport system and the unsustainable existing transportation in Monterrey. 


\subsection{Water management}

Barcelona has potable-drinkable water network throughout the city, in almost every single home and utility in the city, a sewage underground network and sewage waters treatment plant. Curitiba's sewage treatment system utilizes the local lagoons (located near the river) as a water refreshing system - sewage is recycled in three steps: anaerobic, aerobic and discharging treatment - (Soltani and Sharifi). This system in addition to parallel open air canals and designed wetlands is used to control the seasonal floods as well (Brendan [16]). A water management model that integrates the city to the hydrologic cycle to mitigate the human intervention is an example to follow.

Hammarby Sjöstad is aimed to be self-sustainable by having its own rain water collection and filtration system, and its own treatment plant. Their treatment plant is the source of biogas fueling their eco-friendly cars and buses (GlashusEtt [17]). Singapore's efforts to sustainable use of water include the National Water Agency: ABC - "Active, Beautiful and Clean" - Waters Programme. Collection of rainfall, treatment of raw to potable and sewage waters and desalination (PUB [18]). A complete set of facilities and system that are underlined for sustainability.

Monterrey is a water management model in Mexico. 90\% of the city's homes have potable tubed water supply, $93 \%$ of the homes are connected to the sewage network (INEGI [19]), run by a Decentralized Public Institution: “Agua y Drenaje de Monterrey, I.P.D." Even though, the city's rivers have been tubed or channelized compromising the neighboring properties and infrastructure and many of them - Talaverna, Topo Chico, Pesquería - (Gobierno-Municipal-deMonterrey) are conducting waste water to the treatment plants.

\subsection{Alternative energies}

\subsubsection{Solar}

Solar energy has important advantages such as being infinite, free, and nonpollutant energy source, but the existing technology has not get the optimum efficiency. Singapore is the representative case study recognized worldwide for implementing solar energy into urban renovation. Marina Barrage including "The Solar Park" is the largest collection of solar panels in Singapore with 405 panels supply daytime lighting electricity to the barrage's gallery and offices (PUB). The solar park, generates $76,000 \mathrm{kWh}$ electricity per year, which is equivalent to the monthly electricity consumption of about 180 average households in Singapore. Green principles to utilize energy and water efficiently and to minimize waste generated (BCA [20]). The project won the Green Mark Platinum Infrastructure Award (2009), the top award at the Building and Construction Authority - BCA Awards.

Solar technology in Hammarby Sjöstadt delivers 20\% of housing total energy demand. More than $50 \%$ of housing energy demand comes from solar panels, not including heating. The sustainability support were a set of requirement for the residents who must comply a reduction of the power consumption by using low energy devices. The combination of technology and user participation give to the project a sustainable approach not only based in technology but in energy saving 
consciousness. Monterrey's solar exposure is absolutely much more appropriate than Hammarby's to implement this sort of technology in the city integrating them with the existing facilities and the ones to develop.

\subsubsection{Biogas}

There are many advantages of biogas usage of which we must highlight that it is a non-polluting and renewable energy source, it leads to improvement in the environment, sanitation and hygiene, it provides a source of decentralized power generation and it's a technology cheaper and simpler than those for other types of biofuel. In Hammarby Sjöstad, Stockholm, biogas is produced in the waste water treatment plant from the digestion of organic waste or sewage sludge. The waste water from a single dwelling produces enough biogas for the household's gas cooker. Biogas supplies fuel for eco-friendly cars and buses of the whole district (GlashusEtt).

\subsubsection{Wind farm}

In June 2013, the first wind farm project in Monterrey started-up: Santa Catarina Wind Farm. A public-private partnership that was promoted, designed and built up by the private sector with a public investment of 50 million US dollars. The project includes eight General Electric wind turbines with a 22 Megawatts capacity. The eight turbines are a first phase of a 48 wind turbines project. Three private partners join this venture: Next Energy - a local enterprise from Monterrey, Conduit, Capital Partners - an equity investment firm from New York, and Comexhidro Viento - a Mexican construction firm from Mexico City. The importance of this partnership in Monterrey is that sets up a business model and establishes an example for the emerging business of the alternative energies in Mexico and Latin America. Today, the local leading cement industry is promoting wind farm projects. It is a huge step forward that the private sector and the industry in Monterrey get interested in the alternative energies business.

\subsection{Waste management and recycling}

Barcelona city does Recycling via classification, by separating organic waste, aluminum, glass and complemented with an Automat truck waste collection system. Similar to Barcelona, Singapore's National Environmental Agency has developed its own Solid Waste Management and Recycling systems. While the Barcelona and Singapore strategy is based on technology for recycling, Curitiba decided to approach directly to people.

Curitiba's plan combined social with environmental purposes and strategies. Plans are lined up with a common purpose: sustainability. Therefore the recycling programme "Garbage that is not Garbage" is aligned with "Green Exchange" programme that buys the garbage. The achievement is reflected in $70 \%$ of the city trash recycled by citizen, and the preservation of 1,200 trees/day. In Hammarby Sjöstad there is a Recycling Vacuum system for solid waste and refuse sorting, conducting from dwelling to industry by a pressurized, tubed underground network (GlashusEtt, [17]). The difference in Hammarby relies on the recycling culture. 
Monterrey has an automatic truck collections system for all the solid waste, there is still a lack of culture and a lack of policies promoting programmes to implement the waste sorting and recycling culture. Curitiba is an example to Monterrey because their governmental efforts through policies and programs had led to a citizenship's consciousness, a social participation and an environmental culture in every social stratum.

\section{Conclusion}

The city of today needs to face demands on quality of life, quality of the surroundings and offer possibilities to move towards the path of sustainable development with technology as a support. Barcelona, Curitiba, Singapore and the district of Hammarby Sjöstad give alternatives for revitalizing the city providing quality of life and quality spaces without leaving aside the built environment, economy and more especially social urban space. Barcelona proves different alternatives along epochs and evolving contexts of the city.

Solutions towards sustainable development not necessarily set aside technology but require an integrative combination and interrelation of the dimensions: a governance-driven economy with an efficient collaboration in-between the different governmental level and a proactive role of the private sector, technology implementation - through innovation, adaption or adoption-, social inclusion and citizenship sense promotion - via education, recreation, health (physical and psychological), a robust set of public services offer and quality of life-, environment: natural (conserving resources) and built or modified by the human being like our own cities.

In Monterrey there has been a historical lack of a formal city planning which integrates all dimensions that conform a smart-sustainable city. The analysis of Monterrey unbound the opportunities of the city to prevent fragmentation and on the contrary to lead the city towards the tracks of sustainable development. We have identified a variety of feasibility decisive factors towards the sustainable development path of a city, some of them are:

- Promote an extensive, dense and accessible public transport infrastructure.

- Promote a dynamic and diverse economy in the area, through a governance culture and the adequate policies.

- Offer attractive schemes to catch foreign investment: Ensure your investors' satisfaction (Wakefield [21]).

- Achieve international positioning for its quality of life offer.

- Human resources prepared for the future: Quality of education, to set or adopt new trends and technologies, important for its innovation and creativity impact.

- Excellent Quality of Life: Measured by the access to high quality education institutions and health care system. A great connectivity with a widespread public transport network with IT control and monitoring system, and a system of nature parks surrounding the city.

- Public-private co-operation: A key in urban transformation (Socrates) and evolvement of the cities. 


\section{References}

[1] WCED. (1986). Our Common Future, Chapter 2: Towards Sustainable Development. Retreived from UN Documents. Gathering a body of global agreements.: http://www.un-documents.net/ocf-02.htm

[2] Soltani, A., \& Sharifi, E. (2012). A case study of sustainable urban planning principles in Curitiba (Brazil) and their applicability in Shiraz (Iran). International Journal of Development and Sustainability, Vol. 1. ISSN: 2168-8662, 120-134.

[3] Chourabi, H., Gil-Garcia, J., Sehl, M., Nahon, K., Nam, T., Pardo, T. A., Walker, S. (2012). Understanding Smart Cities: An Integrative Framework. Hawaii International Conference on System Sciences, 2289-2297.

[4] Gaffney, A., Huang, V., Maravilla, K., \& Soubotin, N. (2007). HAMMARBY SJOSTAD Stockholm,Sweden: A Case Study. Urban Design in Planning, 1-82.

[5] Aguilar Villanueva, L. (2006). Gobernanza y gestión pública. México, D.F.: Fondo de Cultura Económica.

[6] Socrates, N. (2012). The Barcelona Model. London Metropolitan University, 23-36.

[7] Williams, T. (2006). Information Technologies for Construction Managers, Architects and Engineers. NY: Delmar Cengage Learning.

[8] Odendaal, N. (2003). Information and communication technology and local governance: understanding the difference between cities in developed and emerging economies. Computers, Environmental and Urban Systems. Vol. 27(6), pp. 585-607.

[9] Casellas, A. (july de 2006). Las limitaciones del "Modelo Barcelona". Una lectura desde Urban Regime Analysis. Salt Lake City, Utah, USA.

[10] Henderson, J. C. (2012). Planning For Success: Singapore, The Model CityState? Journal of International Affairs. Vol. 65, No. 2, págs. 69-83.

[11] Leon, N. (2008). Attract and Connect: The 22@Barcelona innovation district and the internationalisation of Barcelona business. Innovation: Management, Policy \& Practice. Vol. 10, Issue 2-3, 235-246.

[12] Barcelo, M. (2006). Presentation of 22@Barcelona. District of Innovation tu Urban Cluster. Barcelona.

[13] LTA. (1996). A World Class Land Transport System. Singapore: Land Transport Authority. Singapore, L. T. (February $\left.11^{\text {th }}, 2014\right)$. Intelligent Transport Systems. Retreived from http://www.lta.gov.sg/content/ltaweb/ en/roads-and-motoring/managing-traffic-and-congestion/intelligenttransport-systems.html

[14] Tuan, F. (2000). An advanced demand management instrument in urban transport. Elsevier Science Ltd., 33-45.

[15] Gobierno-Municipal-de-Monterrey. (2011). Plan de Desarrollo Urbano de Monterrey 2010-2020. Monterrey: Ayuntamiento de Monterrey.

[16] Brendan, I. (1998). Cities that Work. U.S. News \& World Report, Vol. 124 No. 22, 26. 
[17] GlashusEtt. (jan, 2007). Hammarby Sjöstad: The Best Environmental Solutions in Stockholm. Retreived from: http://www.hammarbysjostad.se/inenglish/pdf/Bestenveng.pdf

[18] PUB. (march, 2014). Marina Barrage/Reservoir. Retrieved from Singapore's National Water Agency: http://www.pub.gov.sg/Marina/Pages/3-in-1-benefits.aspx

[19] INEGI. (2005). Instituto Nacional de Estadística y Geografía. Retreived from: http://www.inegi.org.mx/lib/olap/consulta/general_ver4/MDXQuery Datos.asp?proy=sh_pvmg?s=est

[20] BCA. (2014, March 09). Building and Construction Authority. Singapore Government. Retrieved from:

http://www.bca.gov.sg/greenmark/green_mark_projects.html

[21] Wakefield, C. (2006). European Cities Monitor. 34-36. 